\title{
CADPS2 Gene
}

National Cancer Institute

\section{Source}

National Cancer Institute. CADPS2 Gene. NCI Thesaurus. Code C158575.

This gene is involved in the regulation of neurotransmitter and neuropeptide exocytosis. 